has not been, and in some quarters there is not at the present time, that straightforward dealing with the question to which the advocates of more science think they are entitled. The reluctance of the literary people to yield up a fair proportion of the time-table to the modern studies lies at the root of the matter. It is now a question of curriculum, and even in the schools which boast laboratories and appliances the controversy will never end until this barrier is overcome. It is, therefore, particularly gratifying to observe the attitude of the Headmasters' Conference as represented by the resolutions printed in NATURE of January 4 (p. 359). Among the resolutions passed the following is conspicuous :-

(a) That it is essential to a boy's general education that he should have some knowledge of the natural laws underlying the phenomena of daily life, and some training in their experimental investigation. (b) That, in the opinion of this Conference, this can best be ensured by giving to all boys adequate courses of generalised science work, which would normally be completed for the ordinary boy at the age of sixteen. (c) That, after this stage, boys who require it should take up science work of a more specialised type.

Nothing can be better as a statement of a generalised opinion, and we may hope that headmasters will see that it is put into practical effect. There is some ground for belief that this hope will not be in every case disappointed. The address delivered on Tuesday, January 9, by the Rev. J. R. Wynne-Edwards as president of the Inporated Association of Headmasters (see NATure, January I I, p. 380 ) does not appear to be the utterance of a man who is toying with the question, and the distribution of hours at the Leeds Grammar School, of which he is headmaster, would doubtless be found more satisfactory than in some other places. There is not great divergence of opinion in respect to fundamental principles, if we except a comparatively few extreme partisans on both sides. But a satisfactory position is not allotted to the natural sciences in those schools in which an engineering or military side composed of specialists has been established, while the majority of the boys in the school-namely, those to be found on the classical side, which includes many of the best-are put off with two hours a week or less in a time-table which covers thirty hours for other subjects. It is not the function of the schools to provide a body of scientific specialists, but every boy and girl in the kingdom should have time and opportunity for the acquisition of some degree of familiarity with the chief methods and conclusions of the observational and experimental sciences. Concentration on special or technical matters should not be encouraged before the age of sixteen or seventeen, and should not be sought in the curriculum of a general education. The testimony of a business man on this point ought to serve to correct the views of many parents, and it is worthy of notice that Mr. W. L. Hichens (chairman of Messrs. Cammell Laird and Co.), in an important paper contributed to the same meeting, expressed the opinion that "specialised education at school was of no practical value." NO. 2466, VOL. 98]
On the second day of the meeting (January ro) a paper was read by Mr. A. D. Hall, F.R.S., a Development Commissioner and formerly director of the Rothamsted Experimental Station, on "A General Course of Science for the Secondary School." Mr. Hall made no claim for any kind of training directly applicable to industry. $\mathrm{He}$ desired to see a broad and liberal treatment of science, and in the outline he proceeded to sketch he included a larger share than is customary of studies in the domain of biology. In doing this he was not afraid of the charge of smattering. It would be interesting indeed to look into the details of his scheme of work, remembering that this is the outcome of the mature experience of a former schoolmaster. Mr. Hall was at one time chief science master in King Edward's School, Birmingham.

A paper by Mr. A. C. Benson, Master of Magdalene College, Cambridge, read before the Royal Society of Arts on December 20 on the subject of "Literature and Science in Education," will be welcomed by all teachers of science and others interested in progress towards the compromise which must be arrived at if peace is to be secured. Mr. Benson is a well-known literary man with full experience as a teacher, having been for twenty years a master at Eton. It is all the more gratifying, therefore, to find the conciliatory spirit, the liberality of view, and the freedom from prejudice which pervade his paper. It is impossible adequately to summarise it, and it should be read especially by headmasters. One point on which he lays emphasis is the importance of securing good and enthusiastic teachers, and this implies the necessity for rendering the teaching profession more attractive than it has been in the past. With regard to subjects he says: "I do not believe in intellectual progress being possible without intellectual interest" - a view which will be generally acceptable to the present generation, even among those who are not old enough to look back to the time when Latin grammar with plenty of cane was looked upon as the one effectual and economical basis of education.

\section{LORD CROMER, O.M., F.R.S.}

NOT only those who have worked in Egypt, but 1 all who are interested in that country, will have learned with deep regret of the death of Lord Cromer on Monday last, January 29.

On returning to Egypt in $188_{3}$, six years after his first appointment there as a Commissioner of the Debt, Lord Cromer found the country in a state of administrative chaos after the suppression of Arabi's rebellion, while bankruptcy appeared imminent. In the Sudan, troubles were already assuming a threatening aspect, and the dervish revolt was shortly to take place. Under such conditions the most urgent needs were to reorganise the administration of the country, and to re-establish its financial position by developing the great agricultural resources of the Nile Valley and Delta. The provision at the International 
Convention at London in 1885 of a million sterling to be devoted to irrigation was the first step towards the regeneration of Egypt, which has since'gone on with scarcely a check on the lines which he then laid down. Those first six or seven years were years of rigid economy, when all expenditure had to be strictly curtailed and every source of revenue carefully husbanded, but by 1890 the race against bankruptcy was won, and it became possible to deal more generously with various branches of the Administration.

Lord Cromer was always keenly sympathetic towards education, and year by year as means became more ample the grants for it were increased. Schools for elementary vernacular education and secondary and technical schools were established in constantly increasing numbers throughout the country, while the training of teachers to staff them was likewise taken in hand. In a Mohammedan country the education of the female population always presents especial difficulties, but an ever-increasing number of girls' schools have gradually been established throughout Egypt.

Efficient irrigation of the cultivable land being the prime necessity of Egypt's existence, the first grant which made the restoration of the Delta Barrage practicable was followed by many others, and Lord Cromer supported unceasingly the demands of the irrigation engineers until the present system of dams, barrages, and distributing canals had been, if not completed, at least largely achieved. Closely related to irrigation is the agriculture of the country, and the investigations necessary to improve the principal crops had always his warm support.

"The principal function of Government," said Lord Cromer in his report for the year 1903, "is the prevention of epidemic diseases," and to provide adequately for the sanitation of the country was increasingly his care as resources became greater. Recent visitations of cholera and bubonic plague have shown how much success has been obtained in this direction; while the hospitals and medical schools which now exist have made many forget the appalling conditions which prevailed in that country forty years ago.

The geological survey and the cadastral survey of Egypt, from which developed the recent geodetic work in the Nile Valley, are further instances of the way in which Lord Cromer encouraged the more scientific aspects of work of practical importance.

In Egypt archæology has a vast and important field of activity, and while his own interests were most closely connected with the classical period, Lord Cromer supported all projects for the better conservation of ancient buildings and the investigation of the past history and the ancient civilisation of the country. To his advocacy we owe the systematic study of the Nile Valley in Nubia, which, besides the archæological results, has yielded in the hands of Prof. Elliot Smith such important evidence relating to the Egyptian race.

No. 2466 , vol. 98]
After his retirement from Egypt his interest in science led him, by becoming president of the Research Defence Society, to aid the opposition to the ignorant outcry against vivisection, since he recognised its importance in furthering the advancement of medicine and surgery. In I9II he was elected a fellow of the Royal Society as one who had rendered service to science.

Laden with heavy responsibilities of administration, and fully occupied by the many problems which Egypt presented, he still found time to take interest in all new investigations which were being undertaken; his kindly advice and powerful aid were always available to those who were playing their part in the reconstruction of Egypt, and to them he was one on whose support they could always confidently depend. H. G. L.

\section{NOTES.}

Among the list of honours conferred by the King on officers of the Army, the Royal Army Medical Service has reason to be gratified by the number bestowed upon its members. Sir Alfred Keogh, the DirectorGeneral, is promoted to be G.C.B., shaning this distinction. with Sir William Robertson. Sir Alfred Keogh was a former Dinectur-General of the Army Medical Service, and subsequent to his retirement became rector of the Imperial College of Scienoe and Technology, but soon after the outbreak of war was recalled to his former posit. He found the Royal Army Medical Service confronted with a task of the first magnitude, and its staff numerically wholly inadequate to cope with the work before it. Within a few months he made a new force of it; numbers of the younger medical practitioners were ennolled in its ranks, and senior members of the medical profession-physicians, surgeons, hygienists, and specialists in all brancheswere attached to it in a consultative capacity. For two years this virtually new force has worked harmoniously and efficiently. Never before have the wounded been so promptly and so adequately cared for, while the prevention of the numerous diseases which are so liable to follow on war and the train of an army has never been more successfully accomplished.

The King has been pleased to confer the Com. panionship of the Order of the Bath, for services rendered in connection with the war, upon Lieut.-Col. G. H. Barling, vice-chancellor of the University of Birmingham, who is now serving as a consulting surgeon to the British Army in France. The honour of Companionship of the Order of St. Michael and St. George has also been oonferred for war services upon Major Bertram Hopkinson, F.R.S., professor of mechanism and applied mechanics, Cambridge University

We regret to see in the Morning Post of January 30 the announcement of the death, at eighty-two years of age, of Mr. John Tebbutt, of Windsor, New South Wales, where he had an observatory and carried on very valuable astronomical work for many years.

Surgeon-Genl. Sir G. H. Makins will deliver the Hunterian oration before the Royal College of Surgeons of England on Wednesday, February 14. The subject will be the influence exerted by the military experience of John Hunter on himself and on the military surgeon of to-day. 